\title{
Combining Ability Studies for Forage Yield and Its Components in a Diallel Cross of Pearl Millet
}

\author{
YAHIA DAWOUD ELDIE \\ Department of Biological Science, Faculty of Education, Al Fashir University, Alfasher, Sudan
}

\begin{abstract}
Combining ability and interrelationships information was derived on eight agronomic traits including the time to $50 \%$ flowering, plant height, tiller no. /plant, fresh weight of plant, stem thickness, green forage yield, leaf area/plant and leaf area index, from a diallel cross involving five diverse pearl millet (Pennisetum glaucum) parents, developed in ICRISAT. The parents along with their crosses (excluding reciprocals) were grown in a complete block design with three replications at the University of Gezira Farm, July 1999. The objectives of this study were to measure and evaluate combining ability for forage yield and to explore the possibility of developing high forage yielding open-pollinated varieties and/or hybrids .Significant variability among entries was observed for all the traits measured except time to $50 \%$ flowering. The entries were also significantly different for all characters concerning their means ranking. The present study indicated predominantly non-additive gene action for most of the studied traits. However, considerable additive gene action was also indicated for the characters' plant height, fresh weight of plant and leaf area/plant. It was observed that good general combiners for forage yield were AlPop 88, AfPop 90 and Sudan yellow parents. Concerning the incorporation of desirable characteristics, recurrent selection can be efficiently used for making improvements in yield. The best crosses for forage yield were AfPop 90 X Sudan yellow (38.75 t/ha) and AfPop 88 X AfPop 90 (44.48 t/ha).
\end{abstract}

Keywords: Combining ability, Forage, Pennisetum glaucum, a diallel cross

DOI: $10.7176 / \mathrm{JBAH} / 11-6-04$

Publication date:March $31^{\text {st }} 2021$

\section{Introduction}

Pearl millet accounts for more than half of the total worldwide production of all millets. It is the sixth most important cereal crop in the world, next to maize (Zea mays L.), rice (Oryza sativa L.), wheat (Triticum aestivum L.), barley (Hordeum vulgare L.), and sorghum [Sorghum bicolour (L.) Moench] (FAOSTAT, 2014). The crop was grown for forage in America and Australia on areas of 0.12 and 0.03 million ha giving of 1500 and $806 \mathrm{~kg} / \mathrm{ha}$, respectively (FAO,1995). Knowledge of different kinds of gene action and their relative magnitude in controlling various characters is essential for the efficiency of a breeding program.

Combining ability in crops leads to the identification of parents with general combining ability (GCA) effects and locating cross combinations, showing high specific combining ability (SCA) effects (Mathur and Mathur, 1983). Sharma et al., (1987) in a diallel design to evaluate combining ability for fodder yield, concluded a preponderance of non-additive effects and interrelation of combining ability and genetic diversity. The diallel cross designs are frequently used in plant breeding research to obtain information about genetic properties of parental lines or estimates of general combining ability (GCA), specific combining ability (SCA) and heritability reported by Iqbal et al. (2007). Based on combining ability analysis of different characters, higher SCA values refer to dominance gene effects and higher GCA effects indicate a greater role of additive gene effects controlling the characters. If both the GCA and SCA values are not significant, epistasis gene effects may play an important role in the genetic of characters (Sprague and Tatum, 1942). The diallel design has been widely used in pearl millet breeding to assess the type of gene action for grain yield (Bhadaliaet al., 2014). The line $\times$ tester has been adopted to assess the combining ability of inbred parents (Arulselvi et al., 2009) to establish their potential to develop superior hybrids for grain quality traits (Parmar et al., 2013). It has also been used to assess gene action and heterosis for micronutrients like zinc and iron content (Govindarajet al., 2013), combining ability for dry fodder yield (Chaudhary et al., 2012). Traits like grain and fodder yield are governed by polygenes with complex gene action (Jain and Patel, 2014); hence understanding the gene action would help plant breeders in selecting appropriate breeding methods. The objectives of this work to evaluate the GCA of the parents and their SCA in crosses used for the development of high yielding cultivars and to compare the forage yield of parents and their hybrids.

\section{Materials and Methods}

The genetic material used in this study was provided by Millet and Sorghum improvement program at Gezira Research Station (GRS), Agricultural Research Corporation (ARC), Wad Medani, Sudan. The material is a product of a diallel set of crosses produced and evaluated at the International Crop Research Institute for Semi-Arid Tropics (ICRISAT) Asia Centre (IAC) among 11 populations of pearl millet. The current experiment was conducted using a randomized block design with three replications on vertisol soil, at the University of Gezira Farm, Nesheshiba, 
Wad Medani, Sudan (Latitude $14^{\circ} 5^{\prime} \mathrm{N}$, and altitude $33^{\circ} 38^{\prime} \mathrm{E}$ ) in the rainy season of 1999 . Plots were two rows of $6 \mathrm{~m}$ length spaced $0.75 \mathrm{~m}$ apart. Sowing was done in hills spaced $0.3 \mathrm{~m}$ apart with the hills thinned to three plants per hill. Nitrogen fertilizer was applied in the form of urea at sowing, at the rate of $40 \mathrm{~N} \mathrm{~kg} / \mathrm{ha}$. The field was hand weeded three times and irrigated twice during the rainy season. At 50\% flowering, the central two rows of each plot were harvested manually. Measurements were taken on the following parameters: time to $50 \%$ flowering, plant height, tiller no. /plant, fresh weight of plant, stem thickness, green forage yield, leaf area/plant and leaf area index. All statistical analyses were carried out using the software package Genstat version 4 from Rothamsted Experimental Station, U.K. General and specific combining abilities for the studied traits were estimated according to Griffing (1956).

\section{Results and Discussions}

Analysis of variance for entries revealed highly significant variability $(\mathrm{P}<0.01)$ in all the traits except for time to $50 \%$ flowering. Thus in plant breeding, significant differences between the entries indicate the effectiveness of selection and diversity in the material tested (Table 1). These results would be useful in choosing populations to use in a breeding program to improve productivity.

Table 1. Analysis of variance for eight forage yield characters in pearl millet.

\begin{tabular}{|c|c|c|c|c|c|c|c|c|c|}
\hline \multirow{2}{*}{$\begin{array}{l}\text { Source of } \\
\text { variation }\end{array}$} & \multicolumn{9}{|c|}{ Mean squares } \\
\hline & DF & $\begin{array}{c}\text { Days to } \\
50 \% \\
\text { flowering }\end{array}$ & $\begin{array}{c}\text { Plant } \\
\text { height }(\mathrm{cm})\end{array}$ & $\begin{array}{c}\text { No. of } \\
\text { tillers/plant }\end{array}$ & $\begin{array}{c}\text { Stem } \\
\text { thickness(cm) }\end{array}$ & $\begin{array}{c}\text { Fresh } \\
\text { weight of } \\
\text { plant (g) }\end{array}$ & $\begin{array}{c}\text { Green } \\
\text { forage } \\
\text { yield } \\
\text { (t/ha) }\end{array}$ & $\begin{array}{l}\text { Leaf } \\
\text { area } \\
\text { index }\end{array}$ & $\begin{array}{l}\text { Leaf } \\
\text { area/plant } \\
\quad(\mathrm{cm} 2)\end{array}$ \\
\hline Replications & 2 & 96.82 & 418.52 & 1.62 & 0.03 & 112289 & 13.51 & 2.00 & 4160098 \\
\hline Entries & 14 & 5.52 & $1066.89 * *$ & $2.29 * *$ & $0.43 * *$ & $132272.91 * *$ & $257.38 * *$ & $3.79 * *$ & $7749790.6 * *$ \\
\hline Error & 28 & 10.9 & 414.95 & 0.01 & 0.18 & 26202 & 113.29 & 1.48 & \\
\hline
\end{tabular}

** Significant at 0.01 level of probability.

Table 2. Analysis of variance for combining ability using Griffing's method 2, model1 in pearl millet forage yields components.

\begin{tabular}{|c|c|c|c|c|c|c|c|c|c|}
\hline \multirow{2}{*}{$\begin{array}{l}\text { Source } \\
\text { of } \\
\text { variation }\end{array}$} & \multicolumn{9}{|c|}{ Mean squares } \\
\hline & DF & $\begin{array}{l}\text { Days to } 50 \% \\
\text { flowering }\end{array}$ & $\begin{array}{l}\text { Plant } \\
\text { Height }(\mathbf{c m})\end{array}$ & $\begin{array}{l}\text { No. of } \\
\text { tillers } \\
\text { /plant }\end{array}$ & $\begin{array}{l}\text { Stem } \\
\text { Thickness } \\
\text { (cm) }\end{array}$ & $\begin{array}{l}\text { Fresh weight } \\
\text { of plant (g) }\end{array}$ & $\begin{array}{l}\text { Green } \\
\text { forage yield } \\
\text { (t/ha) }\end{array}$ & $\begin{array}{l}\text { Leaf } \\
\text { area } \\
\text { index }\end{array}$ & $\begin{array}{l}\text { Leaf } \\
\text { area/plant } \\
(\mathrm{cm} 2)\end{array}$ \\
\hline GCA & 4 & 0.90 & $294.48 * *$ & 0.32 & $0.12 * *$ & $60815.4 * *$ & $153.36 * *$ & $1.59 * *$ & $3273514.7 * *$ \\
\hline SCA & 10 & 2.22 & $361.33 * *$ & 0.94 & $0.15 * *$ & $35402.7 * *$ & 58.77 & 0.81 & $2307335.9 * *$ \\
\hline Error & 28 & 3.60 & 133.32 & 0.20 & 0.06 & 8734.3 & 37.76 & 0.49 & 36048.2 \\
\hline
\end{tabular}

** Significant at 0.01 level of probability.

Combining ability analysis:

Analysis of variance for combining ability (Table 2) showed significant differences among mean squares due to GCA and SCA effects for all the characters except for mean squares due to the number of tillers per plant, days to $50 \%$ flowering, and leaf area index for SCA effects, which indicated the existence of genetic diversity among the parents.

The ratio of GCA/SCA for all traits was less than one, suggesting that the inheritance of these traits was due to non-additive gene action. This indicates that dominance and epistasis interactions seed to be predominant for these traits and therefore heterosis breeding may be gratifying. This was supported by findings of Burton (1959), Lynch, et al., (1995). Meanwhile, Mathur and Mathur (1983) reported that both GCA and SCA are important in the expression of yield and its components. However, it suggested that a breeding methodology that can be exploited both additive and non-additive genetic effects would be most effective in attaining a maximum improvement in the yield and its components in pearl millet. Eldie, et al., (2009) has found a predominance of additive genetic effects for the inheritance of time to $50 \%$ flowering and plant height, whereas, stover, panicle, biomass and grain yields were controlled by non-additive gene action. Gupta et al., (1978) has emphasized the importance of SCA variance for green fodder yield and its components. Thus, non-additive gene effects were more important than additive effects.

The estimates of GCA effects of parents are given in Table 3. Parents AfPop 88 and AfPop 90 were ranked as best combiners. Best parents on basis of combining ability and per se performance were same for forage yield, leaf area/plant, leaf area index and stem thickness, and one parent was common in case of plant height, leaf area/plant, leaf area index, stem thickness and fresh weight of the plant. Consideration of both combining ability and per se performance for selection of parents will give desirable results. Ouendeba et al., (1993) reported that the significance of the mean squares for GCA for most of the traits studied indicates the preponderance of additive gene effects for these traits. The specific combining effects are presented in Table 4. Crosses AfPop 88 X Sudan 
yellow and NWC-C2 X AfPop 90 showed high SCA effects for most of the characters studied. Some of the crosses had high per se performance for example; AfPop 88 X AfPop 90, AfPop 88 X Sudan yellow and AfPop 90 X Sudan yellow while poor performance was shown by NWC-C2 X AfPop 88, AfPop 88 X SenPop and AfPop 90 $\mathrm{X}$ SenPop. Thus the crosses with high SCA effects may not necessarily have a higher per se performance. About combining the ability of the parents in best crosses, it was found that only one cross AfPop 88 X AfPop 90 was due to the interaction of good combiners. The crosses between two good combiners, e.g. AfPop 88 and AfPop 90 for forage, stem thickness, leaf area per plant and leaf area index, NWC-C2 and AfPop 90 for most of the traits studied gave a high performance and high SCA effects in case of NWC-C2 X AfPop 90 while AfPop 88 X AfPop 90 cross revealed low SCA effects. Both SenPop and Sudan yellow parents have considerable negative GCA effects in addition to large negative SCA effects, indicating considerable divergence between them. However, SenPop X Sudan yellow was one of the best crosses for green forage yield. Negative values of GCA and SCA effects were obtained for some parents and their crosses. Hence, this has indicated in pearl millet crosses, both GCA and SCA are important and need to be taken into consideration in the choice of parents and in developing suitable breeding procedures. Patent positive SCA effects in crosses between good x poor and poor x poor could be endorsed to better complementation between favourable alleles of parents involved. The present study has indicated a predominantly non-additive gene action for all characters. However, considerable additive gene action also was indicated for the character's plant hight, fresh weight of plant and leaf area per plant. The present results suggested that AfPop 88 and AfPop 90 populations would be the best parents to initiate a short term breeding program. Alternatively, broad-based populations could be developed for long term recurrent selection using, NWC-C2, Sudan yellow, AfPop 88 and AfPop 90, the parents for forage yield, stem thickness, and plant fresh weight. The best crosses for forage yield were AfPop 88 X Sudan yellow, AfPop 90 X Sudan yellow, AfPop 88 X AfPop 90 and SenPop X Sudan yellow. Under Sudan conditions, the best forage producer's parents, AfPop 88 and AfPop 90 and Sudan yellow could be used directly for commercial production. Parents forage yield is comparable or even higher than that of crosses. This is attributable to the low or absent heterosis in certain crosses. it is concluded that a greater magnitude of the non-additive genetic component of variance relative to additive component favours heterosis breeding, but an absence of commercial exploitation of heterosis diallel selective mating system can be utilized for the release of an additive component of the variance for exploitation through selection procedures.

Table 3. General combining ability effect of parents for different characters in pearl millet.

\begin{tabular}{|c|c|c|c|c|c|c|c|c|}
\hline Parents & $\begin{array}{c}\text { Days to } \\
50 \% \\
\text { flowering }\end{array}$ & $\begin{array}{c}\text { Plant } \\
\text { height }(\mathrm{cm})\end{array}$ & $\begin{array}{c}\text { No. of } \\
\text { tillers/plant }\end{array}$ & $\begin{array}{c}\text { Stem } \\
\text { thickness }(\mathrm{cm})\end{array}$ & $\begin{array}{c}\text { Fresh weight } \\
\text { of plant (g) }\end{array}$ & $\begin{array}{c}\text { Green } \\
\text { forage yield } \\
\text { (t/ha) }\end{array}$ & $\begin{array}{l}\text { Leaf } \\
\text { area } \\
\text { index }\end{array}$ & $\begin{array}{c}\text { Leaf } \\
\text { area/plant } \\
(\mathrm{cm} 2)\end{array}$ \\
\hline NWC-C2 & 0.58 & $-8.56 * *$ & $0.33 * *$ & 0.09 & 23.87 & $-4.55 * *$ & 0.25 & $348.04 * *$ \\
\hline AfPop 88 & -0.28 & 1.57 & -0.02 & 0.10 & 24.65 & 4.63 & 0.34 & $483.82 \% *$ \\
\hline APop 90 & -0.28 & $8.52 * *$ & -0.01 & 0.08 & $79.93 * *$ & 3.57 & 0.41 & $594.68 * *$ \\
\hline SenPop & 0.10 & 3.84 & -0.02 & $-0.19 * *$ & -92.21 & $-5.44 * *$ & $-0.69 * *$ & $-982.16 * *$ \\
\hline $\begin{array}{l}\text { Sudan } \\
\text { yellow }\end{array}$ & -0.13 & 2.31 & -0.27 & -0.09 & -36.26 & 1.79 & -0.31 & $-444.38 * *$ \\
\hline $\mathbf{S E} \pm$ & 0.64 & 3.98 & 0.15 & 0.08 & 31.60 & 2.08 & 0.24 & 64.19 \\
\hline
\end{tabular}

** Significant at 0.05 level of probability.

Table 4.SCA effect for characters measured in a diallel experiment in pearl millet.

\begin{tabular}{|c|c|c|c|c|c|c|c|c|}
\hline parents & $\begin{array}{c}\text { Days to } \\
50 \% \\
\text { flowering }\end{array}$ & $\begin{array}{l}\text { Plant } \\
\text { Height } \\
(\mathrm{cm})\end{array}$ & $\begin{array}{c}\text { No. of } \\
\text { tillers/ } \\
\text { plant }\end{array}$ & $\begin{array}{c}\text { Stem } \\
\text { Thickness } \\
(\mathrm{cm})\end{array}$ & $\begin{array}{c}\text { Fresh } \\
\text { weight of } \\
\text { plant (g) }\end{array}$ & $\begin{array}{l}\text { Green } \\
\text { forage } \\
\text { yield } \\
(\mathrm{t} / \mathrm{ha})\end{array}$ & $\begin{array}{l}\text { Leaf area } \\
\text { index }\end{array}$ & $\begin{array}{c}\text { Leaf } \\
\text { area/plant } \\
(\mathrm{cm} 2)\end{array}$ \\
\hline NWC-C2 x AfPop 88 & -1.13 & -15.86 & -0.72 & $-0.69 * *$ & $-286.98 * *$ & $-14.67 * *$ & $-943.91 * *$ & -0.67 \\
\hline NWC-C2 x AfPop 90 & 1.21 & -5.74 & $2.28 * *$ & 0.27 & $533.52 * *$ & -0.86 & $3636.74 * *$ & $2.55 * *$ \\
\hline NWC-C2 x SenPop & 0.16 & -1.84 & -0.05 & 0.09 & 79.81 & 6.24 & -2.51 & $1.14 * *$ \\
\hline $\begin{array}{l}\text { NWC-C2 } \\
\text { yellow }\end{array}$ & -1.27 & -0.99 & -0.71 & -0.41 & -22.51 & 4.59 & -299.21 & -0.18 \\
\hline AfPop 88 X AfPop 90 & 0.07 & $-33.65 * *$ & -0.40 & $-0.53 * *$ & -134.48 & 4.12 & $-1879.13 * *$ & $-1.31 * *$ \\
\hline AfPop 88 X SenPop & 0.02 & -9.53 & 0.40 & 0.08 & -68.73 & -8.69 & $-416.35 * *$ & -0.30 \\
\hline $\begin{array}{l}\text { AfPop } 88 \text { X Sudan } \\
\text { yellow }\end{array}$ & 1.92 & 12.45 & $0.82 * *$ & 0.24 & 71.16 & 2.75 & $650.34 * *$ & 0.45 \\
\hline AfPop 90 X SenPop & 2.69 & -11.91 & -0.05 & -0.07 & -72.62 & $-10.94 * *$ & $-720.64 * *$ & -0.50 \\
\hline $\begin{array}{l}\text { AfPop } 90 \times \text { Sudan } \\
\text { yellow }\end{array}$ & 0.59 & -4.61 & -0.58 & 0.01 & -86.90 & 1.23 & $-529.60 * *$ & -0.37 \\
\hline $\begin{array}{l}\text { SenPop } \\
\text { yellow }\end{array}$ & -0.42 & 13.48 & $-0.90 * *$ & -0.17 & -64.76 & 7.57 & $-354.53 * *$ & -0.25 \\
\hline $\mathrm{SE} \pm$ & 1.66 & 10.27 & 0.39 & 0.21 & 81.58 & 5.36 & 165.73 & 0.61 \\
\hline
\end{tabular}

** Significant at 0.05 level of probability. 


\section{References:}

Arulselvi, S., Mohanasundaram, K., and Selvi, B. 2009. Genetic analysis of grain quality characters and grain yield in pearl millet [Pennisetum glaucum (L.) R. Br.]. Crop Research (Hisar), 37(1/3), 161-167.

Bhadalia, A.S., Dhedhi, K.K., Joshi, H.J., and Sorathiya, J.S. 2014. Combining ability studies through diallel analysis in pearl millet [Pennisetumglaucum(L.) R.Br.]. International Journal of Agricultural Sciences, 10(1), 57-60.

Burton, G.W. 1959. Breeding methods for pearl millet (Pennisetum glaucum). Agron. J. 51: 409-417.

Chaudhary, V.P., Dhedhi, K.K., Joshi, H.J., \& Mehta, D.R. 2012. Combining ability studies in line $\times$ tester crosses of pearl millet [Pennisetumglaucum(L.) R. Br.]. Research on Crops, 13(3), 1094-1097.

FAO. 199). Food and Agriculture Organization of the United Nations, Production Yearbook p.84, FAO, Rome, Italy.

FAOSTAT. 2014. FAO statistical yearbook. FAO, Rome.

Govindaraj, M., Rai, K.N., Shanmugasundaram, P., Dwivedi, S.L., Sahrawat, K.L., Muthaiah, A.R., and Rao, A.S. 2013. Combining ability and heterosis for grain iron and zinc densities in pearl millet. Crop Science, 53, 507517. http://dx.doi.org/10.2135/cropsci2012.08.0477.

Griffing, B. 1956. Concept of general and specific combining ability in relation to diallel crossing systems. Austr. J. Biol. Sci.9:463-493.

Gupta, V.P., Gupta, S.P., Sidhu, P.S. and Roshan Lal. 1978. Genetics of green fodder yield components in pearl millet II. Combining ability and gene effects. Abstracts, In Proc. Nat. Seminar on Genetics of Pennisetum, Ludhiana 18-19.

Eldie, Y.D., Ibrahim, A.E.S. and Ali, A.M. 2009. Combining ability analysis for grain yield and its components in pearl millet. Gezira Journal of Agricultural Science7(1), 92-101.

Iqbal, M., Navabi, A., Salmon, D.F., Yang, R.C, Murdoch, B.M., Moore, S.S.and Spaner, D. 2007. Genetic analysis of flowering and maturity time in high latitude spring wheat. Euphytica 154:207-218.

Jain, S.K., \& Patel, P.R. 2014. Combining ability and heterosis for grain yield, fodder yield and other agronomic traits in sorghum (Sorghum bicolour (L) Moench). Journal of Plant Breeding, 5(2), 152-157.

Lynch, P.J., Rattunde, E.W., and Frey, K.J. 1995. Inheritance of vegetative growth index and related traits in pearl millet. Crop Sci. 35: 394-396

Mathur, P.N. and J.R. Mathur1983. Combining ability for yield and its components in pearl millet. Indian Journal of Genetics and Plant Breeding 43(3):299-307.

Quendeba, B., G. Ejeta, W.E. Nyquist, W.W. Hanna, and A. Kumar 1993. Heterosis and combining ability among African pearl millet Iandraces. Crop Science 33: 735939.

Sharma, S.S., Gupta, V.P., and Satija, D.R. 1987. Genetic analysis in inbred - varietal diallel cross vis-à-vis diallel with either inbred of varieties for green yield and its components in pearl millet. Jour. Res. Punjab Agric. Univ., Ludhiana.

Sprague G.F. and Tatum, L.A. 1942. General versus specific combining ability in single crosses of corn. J. Am. Soc. Agron. 34:923-932 